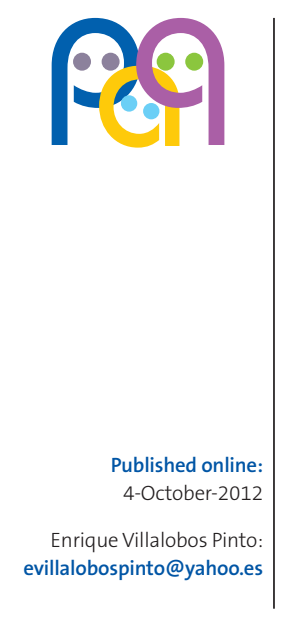

Key words:

- Pertussis

- Complications

- Hospitalization

\section{Original paper}

\section{Risk factors for complications and length of hospital stay in pertussis patients}

\author{
E. Villalobos Pinto, J. Martínez-Villanueva, J. Cano Fernández, P. Flores Pérez, M. Sánchez Bayle
}

Niño Jesús University Hospital. Madrid. Spain.

Objective: to analyze those children admitted to our hospital with the diagnosis of pertussis during the studied period and the relationship of outcomes with different clinical, analytical and/or epidemiologic data.

Material and methods: retrospective study of those patients admitted to hospital with the diagnosis of pertussis in the period 2008-2011. Those cases included accomplish the criteria established by the Centers for Disease Control and Prevention.

Results: 85 patients (54.8\% female), with a medium age of 2.04 months, are studied. Mean time of stay at hospital was of 7.44 days. We found relationship in the multiple lineal regression between the length of stay and the percentage of immature neutrophils $(p=0.006)$, Protein $C$-reactive ( $\operatorname{PrCR}$; $p=0.001)$, oxygen saturation at admission to hospital $(p=0.019)$, apnea $(p<0.001)$ and cyanosis $(p=0.007)$. Rate of admissions to hospital was progressively higher since 2008 .

We have also found an association between the presence of complications and the percentage of immature neutrophils $(p=0.026)$, saturation of oxygen at admission $(p=0.001)$, not having received any dose of vaccine $(p=0.007)$, oxygen $(p=0.001)$, cold symptoms $(p=0.017)$, apnea $(p<0.001)$, cyanosis $(p=0.05)$ and co-infection with viruses (adenovirus and/or VRS; $p=0.044)$.

Two patients died (lethality: $2.4 \%$ ). We found relationship in the logistic regression between the mortality and the number of leucocytes $(p=0.016)$, neutrophils $(p=0.016)$, lymphocytes $(p=0.016)$, immature neutrophils $(p=0.001), \operatorname{PrCR}(p=0.039)$ and procalcitonin $(p=0.023)$ at admission to hospital.

Conclusions: the presence of apnea and cyanosis at the beginning of clinical symptoms, ant not having received any dose of DTPa vaccine, and higher levels of PrCR at admission to hospital can be considered risk factors of a higher length of stay at hospital.

The higher percentage of immature neutrophils and level of procalcitonin, and a lower oxygen saturation at admission, not having received any dose of vaccine DTPa, the presence of cold symptoms, apnea and cyanosis at the beginning of symptoms and the co-infection with respiratory viruses, can be considered risk factors of complications during the hospital admission because of pertussis.

\title{
Factores de riesgo de complicaciones y duración del ingreso hospitalario en pacientes con tos ferina
}

Objetivo: analizar a los niños ingresados con el diagnóstico de tos ferina en nuestro centro en el periodo estudiado y la relación de su evolución con diferentes datos clínicos, analíticos y/o epidemiológicos.

Material y métodos: estudio retrospectivo de los pacientes ingresados en nuestro centro con diagnóstico de tos ferina en el periodo 2008-2011. Se incluyen en el estudio los casos que cumplen los criterios establecidos por los Centers for Disease Control and Prevention.

Resultados: ese estudian 85 pacientes (54,8\% niñas) con una edad media de 2,04 meses. El tiempo medio de ingreso hospitalario fue de 7,44 días. Se encontró relación en la regresión lineal múltiple entre la duración del ingreso con el porcentaje de cayados $(p=0,006)$, proteína $C$ reactiva $(\operatorname{Pr} C R)(p=0,001)$, saturación de oxígeno al ingreso $(p=0,019)$, apnea $(p<0,001)$ y cianosis $(p=0,007)$. La tasa de ingresos aumentó progresivamente desde el año 2008. 
También se objetivó asociación entre la presencia de complicaciones y el porcentaje de cayados $(p=0,026)$, saturación de oxígeno al ingreso $(p=0,001)$, no haber recibido ninguna dosis de vacuna $(p=0,007)$, oxigenoterapia $(p=0,001)$, síntomas catarrales $(p=0,017)$, apnea $(p<0,001)$, cianosis $(p=0,05)$ y coinfección con virus (virus respiratorio sincitial $y / 0$ adenovirus; $p=0,044$ ).

Fallecieron dos pacientes (letalidad, $2,4 \%$ ). Se observó relación en la regresión logística entre la mortalidad y el número de leucocitos $(p=0,016)$, neutrófilos $(p=0,016)$, linfocitos $(p=0,016)$, cayados $(p=0,001), \operatorname{PrCR}(p=0,039)$ y procalcitonina $(p=0,023)$ al ingreso.

Conclusiones: la presencia de apnea y cianosis al comienzo del cuadro clínico, así como no haber recibido ninguna dosis de vacuna DTPa y mayores niveles de PrCR en el momento del ingreso pueden ser consideradas factores de riesgo mayor duración del ingreso hospitalario por tos ferina.

Palabras clave:

- Tos ferina

- Complicaciones

- Hospitalización

El mayor porcentaje de cayados y nivel de procalcitonina, así como menor saturación de oxígeno, en el momento del ingreso; no haber recibido ninguna dosis de vacuna DTPa; la presencia de síntomas catarrales, apnea y cianosis en el comienzo del cuadro y la coinfección por virus respiratorios se pueden considerar factores de riesgo de la aparición de complicaciones durante el ingreso hospitalario.

\section{INTRODUCTION}

Whooping cough is an endemic, acute respiratory infection caused by Bordetella pertussis. It is a highly contagious infection with transmission rates that border on $100 \%$, which is acquired through direct contact with the mucous secretions of the respiratory tract of infected individuals, or through inhalation of the droplets that are disseminated by coughs.

The estimated mortality rate in our environment is lower than $1 \%$. Out of all deaths, $84 \%$ happen in children younger than six months. The following are considered risk factors for a poor prognosis: infant younger than two months, female sex, leukocytosis and pneumonia at the initial presentation, mechanical ventilation indicated due to pneumonia, and development of pulmonary hypertension ${ }^{1}$.

The diagnosis is based on the pertussis case definition established by the Centers for Disease Control and Prevention $(C D C)^{2}$ :

- Clinical case: a cough illness lasting at least two weeks with some of the following symptoms: paroxysms of coughing, inspiratory whoop, or post-tusive vomiting, where there is no other apparent cause.

- CConfirmed case: clinical case and positive culture of nasopharyngeal secretions, identification of B. pertussis DNA by polymerase chain reaction ( $P C R$ ) or positive serologic test; clinical case linked directly to a confirmed case.
- Probable case: clinical case and positive serologic test.

Isolation of a virus does not preclude a pertussis diagnosis.

The objective of our work is to analyse the children admitted to our healthcare centre with a pertussis diagnosis during the period under study, and the relationship between their outcomes and various clinical, analytical and/or epidemiological data.

\section{MATERIALS AND METHODS}

We performed a retrospective, descriptive, crosssectional study.

Out of the 95 patients admitted to our healthcare centre with a pertussis diagnosis between years 2008 and 2011, we selected the 85 that met the criteria established by the CDC for a confirmed case. We gathered the information on the patients admitted with pertussis from the Minimal Basic Data Set Records for Hospital Discharges and Outpatient Surgery (MBDS).

The following data were collected for the patients included in the study from the clinical charts held in our hospital's intranet:

- Demographic data (age, sex). 
- Epidemiological data (immunisation with DTaP and number of doses, cases in the family, length of hospital stay in days, mortality).

- Clinical data (presence of symptoms, complications, admission to the Intensive Care Unit [ICU], relevant procedures, treatment and its duration, prior treatments).

- Analytical data (leukocytes, neutrophils, lymphocytes, platelets, band cells, C-reactive protein [CRP], procalcitonin [PCT] at admission and later tests, PCR, culture, and serological testing for B. pertussis).

We defined the potential complications that could develop during disease progression in the following manner:

- Respiratory: apnoea, pneumonia, pneumothorax, acute otitis media, subcutaneous emphysema.

- Neurological: convulsions, cerebral haemorrhage, and encephalopathy.

- Others: anergy and tuberculosis reactivation, rib fractures, malnutrition, hypoglycaemia, hyponatremia (SIADH), bronchiectasis.

The statistical analysis was performed using the SPSS $^{\circledR}$ software version 15.0 for Windows ${ }^{\circledR}$. We used the Mann-Whitney U-test, the Wilcoxon signedrank test, and Pearson's product-moment correlation coefficient for the study of the quantitative variables. For the study of the qualitative variables, we used percentages and $2 \times 2$ contingency tables, for which we determined the $\chi^{2}$ and the odds ratio. To complete the analysis, we also performed binary logistic regression analysis and stepwise multiple linear regression analysis with backward elimination, and calculated the area under the curve of the model for the complications variable.

\section{RESULTS}

The mean age was 2.04 months, with a standard deviation of 1.44, with the lowest age being 21 days and the highest 13 months, with $54.8 \%$ of those admitted being female and the remaining
$45.2 \%$ male. The average stay in the hospital was of 7.44 days, with a standard deviation of 6.74 , the shortest stay lasting 1 day and the longest 40 days. $25 \%$ of the patients were admitted in year 2008 , $19 \%$ in $2009,27.4 \%$ in 2010 , and the remainder in the first six months of 2011. In 2008, $0.24 \%$ of admissions in our hospital were due to whooping cough cases; the percentage was $0.18 \%$ in 2009 ; and in 2010, pertussis cases amounted to $0.26 \%$ of all admissions.

$40.5 \%$ of the patients had received the vaccine doses that corresponded to their age. $38.2 \%$ had received one vaccine dose, $1.2 \%$ had received two vaccine doses, and $1.2 \%$, three vaccine doses. The remaining $59.5 \%$ had not been given a single dose. A culture positive for $B$. pertussis was obtained in $1.2 \%$ of the cases, no culture was done for $64.3 \%$ of the cases, and the remaining cases produced a negative result. The serological test was positive in $4.8 \%$, was not performed in $81 \%$ of patients, and was negative for the remaining cases.

$47.6 \%$ of patients developed some type of complication, with $65.9 \%$ of all patients requiring oxygen therapy; $29.3 \%$ requiring admission to the ICU; $15.9 \%$ mechanical ventilation, and 1.2\% leukapheresis.

In $44.6 \%$ of the cases there was at least one family member with a history of prolonged cough illness, and in $7.2 \%$ of the cases there was a confirmed case of pertussis in the family.

As for the signs and symptoms, coughing was present in $98.8 \%$, an inspiratory whoop in $35.7 \%$, fever in $14.3 \%$, catarrhal symptoms in $44 \%$, vomiting in $32.1 \%$, apnoea in $31 \%$, and cyanosis in $81 \%$ of the cases.

Co-infection with a respiratory virus (syncytial respiratory virus [RSV], adenovirus) was present in $10.7 \%$ of the patients.

In $2.4 \%$ of cases, the disease caused the death of the patient.

$7.1 \%$ of patients had been treated previously with an antibiotic.

At the time of admission, and relative to the normal ranges established in our centre, $65.5 \%$ of the 
patients presented with leukocytosis ( $>15,000$ leukocytes); only $1.2 \%$ with hyperleukocytosis (> 100,000 leukocytes); $6 \%$ with neutrophilia (> 8,500 neutrophils); 51.2\% with lymphocytosis (> 12,000 lymphocytes); $85.7 \%$ with thrombocytosis (> 400,000 platelets); $3.6 \%$ had a CRP level> $3 \mathrm{mg} / \mathrm{dl}$; and $1.2 \%$ had a PCT level $>0.6 \mathrm{ng} / \mathrm{ml}$, suggesting a bacterial infection; the patients presented an average of $0.47 \%$ band cells, with a standard deviation of 1.21, a minimum of 0 and a maximum of 7 .

In the comprehensive blood panel at the time of admission, $23.8 \%$ presented with leukocytosis, but no patient had hyperleukocytosis; $6 \%$ presented with neutrophilia; 1.2\% with neutropenia (< 1500 neutrophils); $20.2 \%$ with lymphocytosis; $29.8 \%$ with thrombocytosis; $4.8 \%$ of patients had a CRP > $3 \mathrm{mg} / \mathrm{dl}$; and $1.2 \%$, of patients a PCT > $0.6 \mathrm{ng} / \mathrm{ml}$; the patients had an average of $1.04 \%$ of band cells, with a standard deviation of 3.14, a minimum of 0 and a maximum of 14

We found an association between the development of complications and the percentage of band cells and the oxygen saturation level at the time of admission (Table 1).

Of the 85 patients under study, 39 developed complications during the progression of the disease, with the following results: $56 \%$ were female, and the rest were male; only $22 \%$ had received at least one dose of the DTaP vaccine; $84 \%$ required oxygen therapy while hospitalised; $51 \%$ had a family member with a long episode of cough illness, but only $8 \%$ had a family member with a confirmed case of whooping cough. As for the symptoms, $100 \%$ had coughing fits, $27 \%$ an inspiratory whoop, $14 \%$ a fever, $57 \%$ experienced catarrhal symptoms, $35 \%$ experienced vomiting, 54\% apnoeic pauses, and $89 \%$ had cough with cyanosis; co-infection with a respiratory virus was verified in 19\%; and only $3 \%$ had been treated with antibiotics prior to admission.

We found an association between the development of complications and not having received any doses of the vaccine, the need for oxygen therapy, the presence of catarrhal symptoms, apnoea, cyanosis, and co-infection with respiratory viruses (Table 2).

When we performed binary logistic regression, the only variables that remained significant were the percentage of band cells at admission, not having received any doses of the vaccine, and the presence of apnoea (Table 3).

The area under the curve for this model was 0.74 with $p<0.001$ with a $95 \%$ confidence interval $(\mathrm{Cl}$ 95\%) of 0.62-0.86.

The study showed a relationship between mortality and the number of leukocytes, neutrophils, and lymphocytes; the percentage of band cells; and the plasma CRP and PCT levels at the time of admission (Table 4).

Likewise, we found a relationship between the length of the hospitalisation in days and the percentage of band cells at admission, CRP level at

\begin{tabular}{|c|c|c|c|c|}
\hline & Complications & Mean & Standard deviation & $P$ \\
\hline \multirow{2}{*}{ Age (months) } & Sí & 0,17 & 0,17 & \multirow{2}{*}{0,064} \\
\hline & No & 0,17 & 0,07 & \\
\hline \multirow{2}{*}{ Band cells (\%) at admission } & Sí & 0,86 & 1,65 & \multirow{2}{*}{0,026} \\
\hline & No & 0,15 & 0,48 & \\
\hline \multirow{2}{*}{ PCT (ng/ml) at admission } & Sí & 1,34 & 4,55 & \multirow{2}{*}{0,096} \\
\hline & No & 0,08 & 0,07 & \\
\hline \multirow{2}{*}{$\mathrm{O}_{2}$ saturation(\%) at admission } & Sí & 87,43 & 10,57 & \multirow{2}{*}{0,001} \\
\hline & No & 95,39 & 4,45 & \\
\hline
\end{tabular}




\begin{tabular}{|c|c|c|c|c|}
\hline & With complications & Without complications & $\begin{array}{c}\text { OR } \\
(\mathrm{Cl} 95 \%)\end{array}$ & $\mathbf{P}$ \\
\hline Vaccine & $22 \%$ & $51 \%$ & $\begin{array}{l}0,263 \\
(0,087-0,778)\end{array}$ & 0,007 \\
\hline Required oxygen therapy & $84 \%$ & $48 \%$ & $\begin{array}{l}5,413 \\
(1,694-18,057)\end{array}$ & 0,001 \\
\hline Catarrhal symptoms & $57 \%$ & $30 \%$ & $\begin{array}{l}3,029 \\
(1,098-8,481)\end{array}$ & 0,017 \\
\hline Apnoea & $54 \%$ & $14 \%$ & $\begin{array}{l}7,255 \\
(2,217-24,842)\end{array}$ & $<0,001$ \\
\hline Cyanosis & $89 \%$ & $72 \%$ & $\begin{array}{l}3,194 \\
(0,828-13,283)\end{array}$ & 0,05 \\
\hline $\begin{array}{l}\text { Co-infection with respiratory } \\
\text { viruses }\end{array}$ & $19 \%$ & $5 \%$ & $\begin{array}{l}4,783 \\
(0,817-36,115)\end{array}$ & 0,044 \\
\hline
\end{tabular}

admission, and oxygen saturation at admission (Table 5).

We also established a relationship between the length of the hospital stay with the presence of apnoea and cyanosis (Table 6).

The presence of apnoea and higher-than-normal CRP levels at admission remained significant when we performed linear regression analysis (Table 7).

\section{DISCUSSION}

Whooping cough remains an important healthcare problem, and its related hospitalisations affect one demographic group in particular, infants up to six months of age, with a high morbidity rate and a considerable mortality rate ${ }^{3}$.

Table 3. Binary logistic regression results for the association of developing complications with band cell numbers, having received at least one dose of the vaccine, and apnoea

\begin{tabular}{|l|l|l|l|}
\hline & \multicolumn{1}{|c|}{ OR } & \multicolumn{1}{c|}{ Cl 95\% } & \multicolumn{1}{c|}{ P } \\
\hline $\begin{array}{l}\text { Band cells (\%) at } \\
\text { admission }\end{array}$ & 2,553 & $1,238-5,261$ & 0,011 \\
\hline Vaccine & 0,269 & $0,08-0,911$ & 0,035 \\
\hline Apnoea & 9,221 & $2,701-31,483$ & $<0,001$ \\
\hline $\begin{array}{l}\mathbf{R}^{2} \text { : 0,430 } \\
\text { Cl 95\%: 95\% confidence interval; OR: odds ratio. }\end{array}$ \\
\hline
\end{tabular}

The incidence of whooping cough has decreased drastically in industrialised countries thanks to the introduction of the pertussis vaccine in the middle of the last century. However, an increase has been detected in recent years, particularly among adolescents and young adults in Canada, the USA, Australia, and some countries in the European Union ${ }^{4}$.

In 2007, the incidence of whooping cough in the Autonomous Community of Madrid was of 2.78 cases per 100,000 population, a figure that is higher than those of the two previous years. This increase is consistent with the cyclical pattern characteristic of this disease. In 2008, the incidence was of 1.53 cases per 100,000 population. The incidence of whooping cough has shown a sustained increase in the past few years. Starting in 2000, incidences nearing 1.5 cases per 100,000 inhabitants have been recorded, with a characteristic cyclical pattern that peaks at 3-4 year intervals.

At present, the childhood immunisation schedule recommends the administration of five doses of diphtheria, tetanus, and acellular pertussis vaccine (DTaP), at 2, 4, 6 and 18 months and at 4 years of age, and a dose of Tdap at 14 years of age. Still, administration of the dose at 4 years of age did not 


\begin{tabular}{|c|c|c|c|c|}
\hline & Mortality & Mean & Standard deviation & $\mathbf{P}$ \\
\hline \multirow{2}{*}{ Leukocytes/ $\mu$ l at admission } & Sí & 96030 & 9,29 & \multirow{2}{*}{0,016} \\
\hline & No & 20067 & 7,51 & \\
\hline \multirow{2}{*}{ Neutrophils/ $\mu$ l at admission } & Sí & 46990 & 12,25 & \multirow{2}{*}{0,016} \\
\hline & No & 4382 & 1,9 & \\
\hline \multirow{2}{*}{ Lymphocytes/ $\mu$ l at admission } & Sí & 33880 & 0,5 & \multirow{2}{*}{0,016} \\
\hline & No & 13730 & 5,96 & \\
\hline \multirow{2}{*}{ Band cells (\%) at admission } & Sí & 3,5 & 0,7 & \multirow{2}{*}{0,001} \\
\hline & No & 0,39 & 1,11 & \\
\hline \multirow{2}{*}{ CRP (mg/dl) at admission } & Sí & 2,4 & 1,7 & \multirow{2}{*}{0,039} \\
\hline & No & 0,92 & 1,02 & \\
\hline \multirow{2}{*}{ РСТ (ng/ml) at admission } & Sí & 9,2 & 12,17 & \multirow{2}{*}{0,023} \\
\hline & No & 0,12 & 0,05 & \\
\hline
\end{tabular}

start until 1999, and administration of the dose at 14 years of age did not start until 2011. All of the above suggests that the immunity level in the child and adolescent population may be deficient. The national vaccination coverage for the primary series is of $95 \%$ since 1999. In 2008, the national coverage for the basic series (the three first doses) was of $96.9 \%$, the coverage for the first booster dose was $94.9 \%$, and the coverage for the second booster dose $92.3 \%$. The percentage corresponding to the national vaccination coverage with the basic series of the DTaP was $95.9 \%$ in 2009, with a clear decreasing trend since 2002. In the Autonomous Community of Madrid, the vaccination coverage percentage for the basic DTaP series was $88.6 \%$ in 2009 , and a clear decreasing trend had also been seen in previous years ${ }^{4,6}$.

The percentage of patients in our study who had not received any doses of the vaccine was consistent with those reported in other studies performed in Spanish hospitals, but noticeably lower

\begin{tabular}{|c|c|c|}
\hline & R & $\mathbf{P}$ \\
\hline Band cells (\%) at admission & 0,312 & 0,006 \\
\hline CRP (mg/dl) at admission & 0,395 & 0,001 \\
\hline $\mathrm{O}_{2}$ saturation (\%) at admission & 0,335 & 0,019 \\
\hline
\end{tabular}

than those reported in studies performed in other countries $3,7,8$.

The rate of admissions due to whooping cough in our hospital has been increasing progressively since 2008.

Most of the published case series describe a higher incidence in the female sex, a fact that was corroborated in our study 10. However, other studies do not show this clear predominance ${ }^{3,8}$.

The average length of hospitalisation in days is slightly lower than that reported in other studies of similar characteristics ${ }^{3,7}$.

Eln $44.6 \%$ of the cases, there was an adult family member with symptoms that could be attributed to whooping cough who may have been the source of infection, a percentage that is slightly lower than those reported by other studies. Identifying

Table 6. Association of length of hospital stay in days with having received at least one dose of the vaccine, presenting with apnoea, and presenting with cyanosis Length of hospital stay (days)

\begin{tabular}{|l|l|c|c|c|}
\hline \multicolumn{6}{|c|}{ Length of hospital stay (days) } \\
\hline \multicolumn{2}{|c|}{} & Mean & $\begin{array}{c}\text { Standard } \\
\text { deviation }\end{array}$ & P \\
\hline \multirow{2}{*}{ Apnoea } & Yes & 11,35 & 7,65 & \multirow{2}{*}{$<0,001$} \\
\cline { 2 - 5 } & No & 5,69 & 5,51 & \\
\hline \multirow{2}{*}{ Cyanosis } & Yes & 8,22 & 7,19 & \multirow{2}{*}{0,007} \\
\cline { 2 - 5 } & No & 4,13 & 2,36 & \multirow{2}{*}{0,108} \\
\hline \multirow{2}{*}{ Vaccine } & Yes & 5,56 & 3,57 & \\
\cline { 2 - 5 } & No & 8,72 & 8,01 & \\
\hline
\end{tabular}




\begin{tabular}{|c|c|c|c|}
\hline & OR & IC 95\% & $P$ \\
\hline Apnoea & 4,309 & $3,36-9,16$ & $<0,001$ \\
\hline $\begin{array}{l}\text { CRP (mg/dl) at } \\
\text { admission }\end{array}$ & 4,387 & $1,58-4,21$ & $<0,001$ \\
\hline \multicolumn{4}{|c|}{$\begin{array}{l}\mathrm{R}^{2}: 0,314 . \\
\text { CI } 95 \%: 95 \% \text { confidence interval; OR: odds ratio; } \\
\text { CRP: C-reactive protein. }\end{array}$} \\
\hline
\end{tabular}

that a family member has had a prolonged cough illness is important, since it helps make the pertussis diagnosis in the child, and makes it possible to start treating the child and the family members that remain at risk at an earlier time.

As for the symptoms, our study found larger percentages of cyanosis and apnoeic pauses than other studies ${ }^{3,7}$. Consistent with what is reported in the literature, the most frequent symptoms are paroxysmal coughing, inspiratory whoop, and post-tusive vomiting ${ }^{3,7,8}$.

The rate of complications was greater than those reported in comparable studies ${ }^{3}$, but the percentage of cases that required admission to the ICU was similar ${ }^{3}$.

The development of complications as the disease progressed was independent from the age of the patient (a datum that was not consistent with what has been reported by other study groups), and was associated to other clinical and analytical $\operatorname{data}^{3,7,8}$.

Patients who developed complications had a higher percentage of band cells in the differential white blood cell count and higher plasma PCT levels at the time of admission, results which are associated to the presence of bacterial infection. They also presented with lower oxygen saturation levels at the time of admission and required oxygen therapy to recover, which could be due to the fact that most of the complications developed by these patients are respiratory. These data may be considered predictors of the development of complications during disease progression, which would mean that a blood test and monitoring with pulse oximetry is indicated in the initial care of children suspected to have pertussis. This group of patients presented a lower DTaP vaccine coverage rate, although this may be due to the fact that some of the children in the study had not reached vaccination age. For this reason, children younger than two months who have not received any doses of the vaccine are at a higher risk for complications. They also show higher percentages of catarrhal symptoms, apnoeic pauses, and cough with cyanosis in the early stages of the disease, data that continue to support that most of the complications are related to respiratory problems. Whenever these symptoms appear accompanying the typical clinical picture at the beginning of the disease, or in isolation, we should be watchful for the potential development of complications as the disease progresses. Similarly, we observed a higher rate of co-infection with respiratory viruses such as RSV or adenovirus, and therefore recommend that, when complications develop, particularly those of a respiratory nature, a quick test of nasopharyngeal aspirate is performed. When it came to the rate of co-infection with respiratory viruses, the figures reported in other studies were quite disparate, with some being above ${ }^{3}$ the rate we found in our study, and others below ${ }^{7,8}$.

In recent years, lethality has dropped to the figure we found in our study, which is similar to that reported in previous studies ${ }^{3,8}$.

The tests of the only two patients that eventually died showed higher numbers of leukocytes, neutrophils, lymphocytes, higher percentages of band cells, and higher levels of plasma CRP and PCT. These variables can be considered risk factors for a poor prognosis and a severe presentation of the disease with a higher risk of mortality. This is yet another reason why a comprehensive blood test must be done as soon as whooping cough is suspected in a child. Still, these results must be viewed with caution, given the small number of patients deceased.

The patients that developed apnoea and cyanosis at some point in the progression of the disease as well as those who had not been immunised with 
any doses of the DTaP vaccine required longer hospitalisations, as those conditions were associated with a higher rate of complications, and consequently the patient needed more time to improve.

We observed a linear relationship between the CPR levels in the blood test done at the time of admission and the days of hospitalisation required by the patient, so this analytical datum can be considered a predictor for the length of the hospitalisation.

In conclusion, higher percentages of band cells and levels of PCT, as well as a lower oxygen saturation at the time of admission; not having received any doses of the DTaP vaccine; the presence of catarrhal symptoms, apnoea, and cyanosis in the early stages of the disease, and co-infection with respiratory viruses can be considered risk factors for the development of complications during the hospitalisation of patients with whooping cough.

The presence of apnoea and cyanosis in the early stages of the disease, not having received any doses of the DTaP vaccine, and presenting with higher levels of CPR at the time of admission can be consider risk factors for a longer hospitalisation in patients with whooping cough.

The number of hospitalisations due to whooping cough has increased progressively in our healthcare centre during the time covered by our study, while there was a decreasing trend in the DTaP vaccine coverage, which is a cause for concern and highlights the need to improve vaccine coverage in the population.

\section{CONFLICTS OF INTEREST}

The authors declare that they had no conflict of interest in relation to the preparation and publication of this article.

\section{ACRONYMS}

CDC: Centers for Disease Control and Prevention - MBDS: minimal basic data set - DTP: diphtheria, tetanus, and pertussis vaccine - DTaP: diphtheria, tetanus and acellular pertussis vaccine $\bullet \mathrm{Cl}$ 95\%: 95\% confidence interval $\bullet$ OR: odds ratio - PCR: polymerase chain reaction - PCT: procalcitonin - CRP: C-reactive protein - Tdap: combination vaccine: tetanus and low-dose diphtheria and acellular pertussis vaccine - RSV: respiratory syncytial virus $\bullet$ ICU: Intensive Care Unit.

\section{BIBLIOGRAPHY}

1. Tan T, Trindade E, Skowronski D. Epidemiology of pertussis. Pediatr Infect Dis J. 2005;24(5 Suppl):S10-8.

2. Cherry JD, Grimprel E, Guiso N, Heininger U, Mertsola J. Defining pertussis epidemiology: clinical, microbiologic and serologic perspectives. Pediatr Infect Dis J. 2005;24(5 Suppl):S25-34.

3. Martín Jiménez L, Francis Centeno M, de José Gómez MI. Tos ferina. En: Guerrero Fernández J, Ruiz Domínguez JA, Menéndez Suso JJ, Bariios Tascçon A (eds.) Manual de Diagnóstico y Terapéutica en Pediatría, 5.a ed. Madrid: Publimed; 2009. p. 779-83.

4. Namachivayam P, Shimizu K, Butt W. Pertussis: severe clinical presentation in pediatric intensive care and its relation to outcome. Pediatr Crit Care Med. 2007;8(3):207-11.

5. Centers for Disease Control. Pertussis (Whooping Cough). Diagnosis Confirmation [en línea] [actualizado el 24/02/2011] [consultado el 14/05/2012].

Disponible en www.cdc.gov/pertussis/clinical/diagnostic-testing/diagnosis-confirmation.html

6. Beltrán Silva S, Cervantes Apolinar Y, Cherry JD, Conde González C. Consensus on the clinical and microbiologic diagnosis of Bordetella pertussis, and infection prevention. Expert Group on Pertussis Vaccination. Salud Publica Mex. 2011;53(1):57-65.

7. Villuendas MC, López Al, Moles B, Revillo MJ. Bordetella spp. infection: a 19-year experience in diagnosis by culture. Enferm Infecc Microbiol Clin. 2004;22: 212-6.

8. Palmer CM, McCall B, Jarvinen K, Nissen MD. BordeteIla pertussis PCR positivity, following onset of illness in children under 5 years of age. Commun Dis Intell. 2007;31:202-5.

9. Ferrer Marcellés A, Moraga Llop FA, Olsina Tebar M, Campins Martí M, Planells Romeu I. Tos ferina confirmada por cultivo en un hospital terciario en un perioro de 12 años. An Pediatr (Barc). 2003;58:309-15.

10. Servicio de Epidemiología. Sección de enfermedades transmisibles. Dirección General de Atención Prima- 
ria. Servicio Madrileño de Salud. Informe Tos Ferina, año 2007 [en línea] [consultado el 14/05/2012]. Disponible en http://bit.ly/KUYzbO

11. Bettinger JA, Halperin SA, De Serres G, Scheifele DW, Tam T. The effect of changing from whole-cell to aceIlular pertussis vaccine on the epidemiology of hospitalized children with pertussis in Canada. Pediatr Infect Dis J. 2007;26:31-5.

12. Bhatt $P$, Halasa N. Increasing rates of infants hospitalized with pertussis. Tenn Med. 2007;100(5):37-9, 42

13. Fung KS, Yeung WL, Wong TW, So KW, Cheng AF. Pertussis-a re-emerging infection? J Infect. 2004;48:145-8.

14. Cardeñosa N, Romero M, Quesada M, Oviedo M, Carmona G, Codina G, et al. Is the vaccination coverage established enough to control pertussis, or it is a reemerging disease? Vaccine. 2009;27:3489-91.

15. Red Nacional de Vigilancia Epidemiológica de España. Informe anual. Año 2008 [en línea] [consultado el 14/05/2012]. Disponible en http://bit.ly/KUYhBO

16. Therre H, Baron S. Pertussis immunisation in Europe: the situation in late 1999. Euro Surveill. 2000;5(1):6-10.

17. Olin P, Hallander HO. Marked decline in pertussis followed reintroduction of pertussis vaccination in Sweden. Euro Surveill. 1999;4:128-9.
18. Ministerio de Sanidad, Política Social e Igualdad. Coberturas de vacunación, datos estadísticos [en línea] [consultado el 14/05/2012]. Disponible en www. msps.es/profesionales/saludPublica/prevPromocion/vacunaciones/coberturas.htm

19. Horcajada Herrera I, Hernández Febles M, González Jorge R, Colino Gil E, Bordes Benítez A, Pena López MJ. Estudio clínico-epidemiológico de la infección por Bordetella pertussis en la isla de Gran Canaria en el periodo 2003-2007. An Pediatr (Barc). 2008;69:200-4.

20. Elliott E, McIntyre P, Ridley G, Morris A, Massie J, McEniery J, et al. National study of infants hospitalized with pertussis in the acellular vaccine era. Pediatr Infect Dis J. 2004;23:246-52.

21. Servicio de Epidemiología. Boletín Epidemiológico de la Comunidad de Madrid. ․ㅛ 1-12. Volumen 16. Enero-diciembre 2010 [en línea] [consultado el 14/05/2012]. Disponible en http://bit.ly/KUY95a

22. Servicio de Epidemiología. Boletín Epidemiológico de la Comunidad de Madrid. № 1. Volumen 17. Enero 2011 [en línea] [consultado el 14/05/2012]. Disponible en http://bit.ly/KUY55w

23. Munoz FM. Pertussis in infants, children, and adolescents: diagnosis, treatment, and prevention. Semin Pediatr Infect Dis. 2006;17:14-9. 